Article

\title{
Banned Books behind Bars: Prototyping a Data Repository to Combat Arbitrary Censorship Practices in U.S. Prisons
}

\author{
Kate Cauley \\ John Jay College of Criminal Justice, City University of New York, New York, NY 10019, USA; \\ kcauley@jjay.cuny.edu
}

Received: 16 September 2020; Accepted: 26 October 2020; Published: 30 October 2020

\begin{abstract}
Banned Books Behind Bars" is a social justice project that aims to shed light on the complex problem of information access in prison and to explore potential prototypes for possible solutions to some of these obstacles, in particular access to books and printed information. The United States is home to five percent of the world's population but a staggering twenty-five percent of the world's total prisoners. For many incarcerated individuals, access to information is a struggle: censorship, book banning, and lack of adequate library facilities or collections are common. Over the course of conducting preliminary research, this project evolved through the research process of ideation. Through the participatory action research method, qualitative interviews with volunteers from banned books organizations helped to identify potential digital tools meant to aid in the fight against the First Amendment violations that incarcerated individuals face daily. Furthermore, the interviews clarified that the first step toward creating an impactful digital project involves converting various forms of unstructured data, including newspaper articles, prison censorship forms, and state published banned book lists, into structured data. Through this discovery, "Banned Books Behind Bars" became an endeavor to standardize practices of data aggregation amongst banned books organizations throughout the country. Gathering concrete data about the practice of banning books within prisons requires an elevated level of transparency. Incarcerated individuals, their families, and prison reform activists need a platform for reporting data on censorship practices, and, ultimately, for bringing awareness to the arbitrary application of censorship guidelines within the complex world of incarceration. The final prototype is a digital repository, created with Airtable software, which offers authoritative dataset consolidation for activists and organizations working to deliver books to prisoners.
\end{abstract}

Keywords: censorship; digital humanities; information access; banned books

\section{Prison Censorship and Books: An Introduction}

The United States prison system is plagued by arbitrary interpretations of censorship law and unregulated practices of banning books. For most Americans, the rights and protections afforded by the First Amendment of the Constitution are considered inalienable. However, this is not the case for the over 2.3 million Americans currently residing in prisons and jails across the country. Access to information is a constant battle, one which is often not met with the legal and social support that it deserves. Moreover, formal laws which aim to address prison censorship, such as 28 C.F.R. $\S 540.71$ (1979) and Turner vs. Safley (482 U.S. 78 1987), which will be discussed in the following section, defer censorship judgments from the higher courts onto individual prison officials. Consequently, prison officials employ informal interpretations of formal law in such a way as to embody the definition of censorship through "a variety of processes ... formal and informal, overt and covert, conscious and 
unconscious, by which restrictions are imposed on the collection, display, dissemination, and exchange of information, opinions, ideas, and imaginative expression." (Jones 2001, p. 2). Because book banning takes place through subjective interpretation by prison officials, individuals and organizations working toward correcting unconstitutional bans are often met with a diverse set of challenges.

First and foremost, many of the rules concerning access to reading materials are inconsistent prison to prison and state to state in unregulated fashion-frequently left to the discretion of individual prison officials who are free to interpret laws as they see fit (PEN America 2019). Second, data around censored materials and the inequities of access to information is unstructured and difficult to interpret. This lack of clarity can and frequently does obscure violations of prisoners' First Amendment rights. These threats to prisoners' constitutional rights are a result of the United States' hands-off policy towards the prison system and its administrators. Activist Angela Y. Davis observes, "prison relieves us of the responsibility of seriously engaging with the problems of our society, especially those produced by racism and, increasingly, global capitalism." (Davis 2003, p. 16). The "relief of responsibility," addressed here by Davis, extends not only to the general society but also to our government, which has faltered in its attempts to properly protect prisoners' rights to access information.

One possible tool to resolve these two major issues could be the creation of a collaborative digital database that would consolidate censorship data and make it accessible to prisoners, advocates, and the public. A tool of this kind would have the potential to act as legal aid, a research tool, and a civil rights measure. It could also act as an essential social justice resource, returning constitutional rights to the incarcerated. This study proposes such a system that would create data aggregation of censorship in prisons to better position individuals to challenge prison official overreach and civil rights violations. Background information about the problem and the proposed design solution are based upon structured interviews with books-to-prison organizations from various parts of the United States.

\section{Formal Practices of Banning Books: A Brief Legal History}

During the 1970s, the legislative process of defining prisoners' rights to retrieve books and periodicals gained momentum alongside the rise of mass incarceration (James 2018). The ascent of mid-century capitalist ideologies influenced the financial benefit and subsequent exploitation of prison labor. Furthermore, as a consequence of President Richard Nixon's 1971 declaration of the War on Drugs, the enforcement of strict drug policy, which specifically targeted communities of color, exacerbated the country's prison population (ibid.). The quantitative impact of mass incarceration is widely cited by media outlets, politicians, and penological scholars. One such commonly cited statistic is this: "The United States contains only five percent of the world's population but is home to twenty-five percent of the world's prisoners. The incarceration rate is approximately one in every one-hundred American adult."(Bianco 2016) As a rising number of Americans have been sentenced to time in prison, the social and legal implications of mass incarceration were proven to be afterthoughts. Bianco (2016) argues that prison officials have exploited the lack of clarity around prisoners' First Amendment rights in order to selectively interpret the law. This section will trace the history of pertinent legislation and case law, such as Procunier v. Martinez (416 U.S. 396 1974), 28 C.F.R. $\S 540.71$ (1979), Turner v. Safley (482 U.S. 78 1987), and Beard v. Banks (548 U.S. 521 2006) which have aimed to address prisoners' rights to receive books behind bars.

The rise of mass incarceration is mirrored through the modern laws on prisoners' First Amendment right to receive books in tandem with the role of the courts in policing their access to information. In the inaugural case, Procunier v. Martinez (1974), appellees sought class action against arbitrary regulations on mail retrieval and correspondence within prison. While the court argued for the preservation of human inquiry for inmates, it did not prescribe any concrete process for ensuring those rights. The court opined,

When the prison gates slam behind an inmate, he does not lose his human quality; his mind does not become closed to ideas; his intellect does not cease to feed on a free and open interchange of opinions; his yearning for self-respect does not end; nor is his quest for 
self-realization concluded [ ... ] It is the role of the First Amendment and this Court to protect those precious personal rights by which we satisfy such basic yearnings of the human spirit. (Burns 2007, p. 1225)

Although this sentiment, written in 1974, strikes to the heart of the concern raised by both appellees and First Amendment advocates alike, today's government still continues to do little to interrogate the actual processes in place meant to protect said rights. In fact, the legislation that followed ultimately deferred the responsibility of defining censorship violations from the court onto individual prison officials.

The court's ruling in 28 C.F.R. $\S 540.71$ empowers subjectivity by allowing individuals to craft policy, which means book denials often vary between prisons. Title 28 of the United States Code governs the federal judicial system, and therefore has the authority to establish uniform law within the Federal Bureau of Prisons. Moreover, Title 28 demonstrates the court's attempt at defining censorship violations in regard to prisoners' rights to receive mail, and, more specifically, books. This provision affords subjective freedom to prison wardens and officials when determining which books to keep from their inmate population. The court reasons that "the Warden may reject a publication only if it is determined detrimental to the security, good order, or discipline of the institution or if it might facilitate criminal activity." ${ }^{\prime 1}$ Ultimately, this ideology has failed to protect the human rights outlined in Procunier v. Martinez, because it has resulted in unequal access to information for prisoners across the country.

The legality of prison censorship was revisited in the 1987 case of Turner $v$. Safley ${ }^{2}$, where the court attempted to establish a uniform banning procedure, an effort which ultimately failed to rectify the pervasive problem. The Supreme Court formed the Turner Test, a four-part standard of review meant to aid prison officials in their censorship decision process. In order to determine whether an act of censorship is reasonably related to the overall penological concerns of the prison, the Supreme Court outlined four queries for prison officials to examine:

- Whether there is a "valid, rational connection" between the prison regulation and the legitimate governmental interest.

- Whether there are alternative means for the inmates to exercise their constitutional rights.

- Whether the granting of inmate request will negatively impact on guards and other inmates.

- Whether there are any ready alternative ways for the inmate to exercise his rights. ${ }^{3}$

Similar to Title 28, the application of the Turner Test is left in the hands of prison officials, wardens, and, in many cases, mailroom staff. In Turner $v$. Safley, Justice Stevens states, "if the standard [could] be satisfied by nothing more than a 'logical connection' between the regulation and any legitimate penological concern perceived by a cautious warden, it is virtually meaningless" (Burns 2007, p. 1243) The Turner framework passes the responsibility of defining security concerns to the warden or prison officials, and requires no evidence to support those determinations. This is a seemingly impractical and unjust measure which leads to inconsistency of censorship across institutions.

The material effect of the Turner Test is demonstrated in the 2006 case of Beard v. Banks, when the Secretary of the Pennsylvania Department of Corrections, Jeffrey Beard, was challenged on his ban determination by inmate Ronald Banks. Beard $v$. Banks addressed restrictions placed on prisoners in "level 2" of the Long-Term Segregation Unit (LTSU). Inmates placed in level 2 LTSU were routinely denied access to visitors, commissary, newspapers, magazines, books, and personal photographs. The justification made by prison officials for employing such rigid restrictions was that level 2 LTSU

28 C.F.R. $\$ 540.71$ (1979).

Although the Turner Test was originally established as a measure for determining marriage rights, it has since been widely applied to questions of mail, and, ultimately, book retrieval.

Turner vs. Safley, 482 U.S. 78 (1987). 
housed only their most contentious inmates. This might be defensible, if, in fact, the system of placing inmates in this highly restrictive unit was based on a comprehensive evaluation of penological concern. However, as outlined in this case, every new inmate was automatically assigned to this housing unit for a minimum of ninety days. ${ }^{4}$ It was also noted by the court that, as a general practice of the facility, most inmates (approximately three out of four) never graduated to a lower level of security. ${ }^{5}$ Although this information was brought to the attention of the court by Mr. Banks, the court ultimately ruled in favor of the Pennsylvania prison, in a six-to-two vote. Justices Thomas, Stevens, and Ginsburg all criticized this particular application of the Turner Test, as the prison only vaguely connected the restrictions to rehabilitation.

The court's pattern of deferring the responsibility of protecting constitutional rights onto prison officials spans beyond the banning of reading materials. During the 1960s, the "O-wing" of the Soledad Prison in California was subject to a prisoner's federal suit. The conditions in this particular block of cells were inhumane, uninhabitable, and arguably exemplified "cruel and unusual punishment" under the Constitution. In 1966, the presiding judge opined that the conditions of the O-wing "does violence to the elemental concept of decency." (Yee 1973, p. 24). Although the court ruled in the prisoners' favor, little was done to rectify the atrocious living conditions. As noted by prison reform scholar, Larry E. Sullivan:

The decision provided a measure of satisfaction to the prisoners and brought conditions at Soledad to public attention, but few practical improvements resulted. The court could not break entirely from the traditional 'hands-off' policy of not interfering with bureaucratic runnings of prisons, and therefore it did not mandate the implementation of specific procedures by which the correctional system was to comply with the Constitution. (Sullivan 1990, p. 96)

It should be no surprise, then, that a prison system which deprives inmates of moderately clean, properly ventilated, humane living space, might also deprive inmates of their intellectual freedoms.

The court's hands-off policy has resulted in a massive corpus of banned materials. The actual statistics of how many books have been banned is difficult to discern, precisely because so much of the data is displaced and scattered. In Texas alone, there are over 10,000 banned books documented (Haag 2017). The reasons, too, are difficult to discern, but telling of both the ideological opacity and the numerical enormity of banning practices. Moreover, most prison officials making decisions about what texts can circulate to or within prisons lack legal expertise. Individual wardens, guards, and administrators make the determinations and not only do many of them lack legal degrees, but they also frequently have minimal exposure to the actual texts that they censor (PEN America 2019). In other cases, officials have demonstrated decision-making rooted in actual animus, with blanket bans hastily placed on texts addressing LGBTQ+ and racial content (Dean 2016). In some cases, for instance, the only note explaining the ban is 'racial' (Texas Department of Criminal Justice 2020). Furthermore, the subjective nature of Title 28 and the Turner Test has allowed for disparate interpretations of the law. As a result, books are being banned from prison walls based on often racist, homophobic, or simply ignorant interpretations of the texts in question, and not because of legitimate penological concerns.

\section{Informal and Arbitrary Practices of Banning Books}

As discussed in the previous section, the legislative process of book banning in United States' prisons is both overly complex and unsound. The system of analysis for approval or denial requires a more in-depth approach than the Turner Test. By deferring responsibility onto prison officials and mailroom staff, the court is condoning inevitable violations to prisoners' First Amendment rights. It has

\footnotetext{
Beard vs. Banks, 548 U.S. 521 (2006).

Burns, “Beard v. Banks: Restricted Reading, Rehabilitation, and Prisoners' First Amendment Rights," 1254.
} 
become increasingly apparent that prison systems have reimagined formal processes of censorship in order to impose informal and arbitrary banning practices.

The flippancy demonstrated by prison officials and mailroom staff while applying the Turner Test has become increasingly reported on by journalists and advocates alike. In their September 2019 Literature Lock Up report, PEN America outlines two forms of book denials: content-based and content-neutral bans. The former, content-based bans suggest that the content of the book in question presents some reason for penological concern. Common citations made for this type of ban include:

- Sexual content, nudity, or obscenity.

- Depictions of criminal activity or language perceived to encourage it.

- Depictions of violence or language perceived to encourage it.

- Encouragement of "group disruption" or anti-authority attitudes or actions.

- Racial animus or language perceived to encourage hatred. ${ }^{6}$

Although, at first, these justifications may seem reasonable, the concerns outlined above have been reimagined by individual prison employees in order to legitimize arbitrary banning practices. As observed by the Texas Civil Rights Project, "a consequence of this discretion is many arbitrary, unreasonable, and astonishing decisions, as well as regular inconsistencies, largely because material is twisted entirely out of context" (Texas Civil Rights Project 2011). As a result, a surfeit of literary and non-fiction works has been prohibited from the minds of 2.3 million incarcerated men and women.

The insidious implementations of prison censorship are best revealed by the long list of banned civil rights texts. Civil rights lawyer, Michelle Alexander, argues in her book, The New Jim Crow, that mass incarceration is a continuation of racist American policies that have been designed to oppress black and brown individuals. This book, which is commonly assigned in classrooms, heavily cited by scholars, and has received multiple accolades (PEN America 2019), has been banned by prisons in North Carolina, Florida, Michigan, and New Jersey(Bromwich 2018). This is just one example of the many civil rights texts currently banned from United States' prisons. Other examples of banned civil rights works include, Race Matters by Cornel West, Colored People: A Memoir by Henry Louis Gates Jr., Black Skin, White Masks by Frantz Fanon, and Chokehold: Policing Black Men by Paul Butler (PEN America 2019, p. 5). Perhaps the most disastrous consequence of book banning has been the multitude of civil rights texts that have faced prohibition.

Beyond banning books that address race, another civil rights concern is the banning of books with LGBTQ+ content. Often deemed "sexually explicit," books involving same-sex couples are too often subject to bias from prison staff. Reports have indicated that publications such as Out Magazine and Coming Out of the Concrete Closet (a survey on the lives of LGBTQ+ incarcerated men and women) are often denied (Dean 2016). These publications address the LGBTQ+ community. By denying prisoners the right to read them, especially when heteronormative texts are less likely to face the same scrutiny, prisons officials are infringing on the civil liberties of prisoners based upon their sexual orientation.

It is not just the banning of books written about civil rights that should ignite concern from constitutionalists, but also the banning of literary classics which speak to the lived experiences of minorities. The Color Purple by Alice Walker, Native Son by Richard Wright, and Middlesex by Jeffrey Eugenides are just a few examples of the many classic novels that have been barred from various prisons. These works of fiction have been assigned in classrooms and reviewed by literary scholars for decades. However, decisions to deny access to these works are not left in the hands of the scholars who analyze them or the audience who the story aims to address. Instead, prison officials-having read or not read the books in question—are making the judgement on which stories are allowed inside the prison walls (Texas Civil Rights Project 2011).

6 See (PEN America 2019, p. 4). 
Content-based bans have garnered some recent public attention, as journalists have begun to report more and more on the shocking ban decisions made by prison officials. The call for reform has been slow in the decades since the inauguration of the Turner Test. However, in recent years, reports made by major news organizations and prison advocacy groups have fomented some public response (O'Sullivan 2019). Visibility, accountability, and transparency are all key components for igniting actions against unjustifiable, and unconstitutional, bans on innocuous texts.

The second category of bans, as examined by PEN America, is content neutral. In these cases, books are denied regardless of their subject matter. The justification for this practice is that incoming parcels are subject to strict guidelines, as the content may conceal contraband. Again, although this may appear as reasonably related to penological concerns, the application of these bans is oftentimes far too extreme. For example, in December 2017, the New York State Department of Corrections created Directive 4911A. Under this regulation, prisoners were only allowed to receive books from a set of six approved vendors. The books-to-prison organization, Books Through Bars, reported that the catalog consisted of only "five romance novels, fourteen bibles and other religious texts, twenty-four drawings or coloring books, twenty-one puzzle books, eleven guitar, chess, and how-to books, one dictionary, and one thesaurus" (PEN America 2019). Similar regulations have been set in Maryland, Ohio, Pennsylvania, Washington, and more broadly in the Federal Prison System. Fortunately, public outrage led many of these states to reevaluate their policies. However, relying on the public to gain awareness and speak out against unjust book banning policies is not a solid pathway to a more fair and equal prison system. The avenues for public discovery on this topic are narrow and require more public awareness. Policies which restrict both the dimensions of a parcel and specific senders still remain actively enforced. Therefore, books-to-prison organizations continue to face unnecessary challenges while working to provide access to books.

\section{Tracking and Appealing Bans: A Digital Solution}

The application of book banning in United States' prisons is so indiscriminate that tracking decisions, appealing bans, and creating systemic reform seems nearly impossible. Appealing specific book denials is extremely challenging for inmates in most states. Prisoners are required to pay postage fees, exhaust all internal appeals obstacles that an individual person may choose to employ, and even when a prisoner is allowed the opportunity to face an appeals judge, he or she is not allowed prior access to the book in question, making it extremely difficult to draft a proper appeals plea (Bianco 2016).

Heightened public awareness is a key element toward reforming unconstitutional applications of the Turner Test. Currently, data surrounding this topic is unstructured and unconsolidated. State-published lists are challenging to find and are often located behind paywalls on third-party digital libraries, such as Scribd (Louisiana Department of Corrections List of Banned Books and Publications 2018) Although major media organizations are increasing their reporting on this topic, journalistic composition is challenging to utilize for data analysis. In the 2016 article, Prisoners' Fundamental Right to Read: Courts Should Ensure That Rational Basis Is Truly Rational, author Alicia Bianco states,

By keeping these lists confidential, institutions are preventing free citizens from learning about the restrictions and policies. Thus, the public is not often in possession of the necessary information to even understand the abridgement of First Amendment rights that prisoners face. Without this information, those among us who sympathize with prisoners are without the necessary tools to fight for the rights of the incarcerated.

(Bianco 2016, p. 5)

Building on Bianco's observations, the objective of this current project is not merely to articulate the barriers between prisoners and access to knowledge, but also to present a possible solution for combatting these First Amendment violations. This paper argues that through collaboration of digital humanists, books-to-prison organizations, and the general public, systemic change is feasible. 
The remainder of this article will explore potential digital humanities solutions, discovered through the participatory action research that I have conducted with books-to-prison organizations.

\section{Methodology}

This study engages the participatory action research (PAR) method as a means to speak truth to power. Like digital humanities scholarship, the application of collaboration and iteration is inherent to PAR. Action researchers' prerogative is not simply to collect data, but also, "action researchers have an obligation to feed data back into the community with which they collaborated when identifying and solving a practical problem" (Blichfeldt and Andersen 2006, p. 4).

The curation of knowledge and the facilitation of action are two key components of PAR. The Sage Handbook of Action Research conceptualizes that "through action, knowledge is created, and analyses of that knowledge may lead to new forms of mobilization; new solutions or actions are identified, tested, and then tried again" (Reason and Bradbury 2008, p. 12). The objective is not to solve the pervasive problem of unconstitutional bans on books in prisons, but to shed light on the mechanics of the problem to empower organizations and individuals to work towards positive change.

This study's vision for improving transparency and awareness on unjust book banning practices was supported by structured interviews, conducted with various volunteers from books-to-prison organizations across the United States. From the onset of this project, the intention was to gather first-hand information from sources working to provide book delivery services to prisons. The books-to-prison organizations that were interviewed for this study were active participants in this project's framework, and each iteration was informed by their input.

This study's intention is to return the findings back into the community for reevaluation, by submitting a versioned prototype to the organizations which were interviewed for further evaluation and feedback. The following books-to-prison organizations were consulted for this study:

- Read between the Bars (AZ),

- Books to Prisoners (WA),

- Books 2 Prisoners (LA, MS, AR, AL),

- Big House Books (MS),

- Inside Books Project (TX),

- Liberation Library (IL),

- The Prison Book Program (MA), and

- NYC Books Through Bars (NY).

Organizations were chosen based on both geography and incarceration rates (Leins 2019). Programs that serve Missouri, Arkansas, Arizona, Alabama, Louisiana, and Texas were selected based on the state's large prison population. Additionally, this study includes prominent organizations serving major cities, including Seattle, New York, Boston, and Chicago.

This study aimed to gather qualitative information from the above books-to-prison organizations. Additionally, this project engages design thinking to rapidly prototype some possible solutions to their most common problems. In order to gain insider information, interviewees were initially sent structured interview questions through email. The structured interview questions asked to each organization were as follows:

- What have you witnessed in regard to formal vs. informal censorship when it comes to prisons banning reading materials?

- What has been the material effect of these modes of censorship?

- What new and remaining obstacles are creating challenges for your organization?

- What type of digital tools might be helpful to your cause?

Each organization was sent the same set of questions. However, some participants were later contacted over the telephone for follow-up questions. These conversations were not recorded, 
but thorough notes were taken. Lastly, this study uses the content analysis method of qualitative data research in order to identify common threads throughout the interviews.

\section{Limitations}

Feasibility was a chief concern throughout the ideation process. Many others have dedicated their time and energy to this cause. Therefore, there is an unlikelihood of executing a complete panacea, as the challenges that fellow advocates have encountered in terms of data curation and technology preservation have made it clear that no one simple solution will do. The scope of this project was kept within reasonable limits. The objective was not to code and design a live website, but instead to delve into the concerns and goals of books-to-prison organizations, in order to determine a feasible digital solution. Therefore, the goal was simply to create a prototyped solution, which could then be fed back into the community for further evaluations. It is also worth noting the challenges in liaising with volunteers. Limitations were set on their availability and time. In fact, responses were not received from two of the organizations contacted, NYC Books Through Bars and The Prison Book Program. Volunteers are unpaid, and many expressed having multiple occupations outside of book delivery. These limitations were considered throughout both the research and prototyping phase of this study.

\section{Findings}

The method of content analysis was employed in order to interpret the resulting data. Coding schemes identified categorical comments made by the sample. The following categories were present in each interview:

- Finance, cost, or funding;

- Manipulation or subjectivity;

- Complications or difficulties;

- Policy;

- Digital projects.

The sample conveyed similar sentiments toward each of these codes, except "digital projects." Organizations were united in expressing issues of funding, unfair or subjective book bans, difficulties toward information access, and policy concerns. Conversely, the topic of digital projects rendered mixed results. While certain organizations, including Inside Books Project and Big House Books, responded positively to the notion of digital tools; other organizations were more pessimistic about digital intervention. However, the overall results showed common concerns from each books-to-prison organization.

Responses verified existing reports of unnecessarily circuitous pathways for getting books into prisons. One representative from Read between the Bars expressed frustration after receiving conflicting explanations for why their book donations were being returned from Perryville, the only women's prison in Arizona. They faced additional obstacles beyond overt censorship, and, after repeatedly amending their practices to abide by the prison's opaque rules, the cost of repeated return postage became unmanageable. From Read between the Bars' perspective, these restrictions "appeared to be the personal decision of one person at a single facility" (Read between the Bars 2019) The organization reported,

These kinds of manipulation maneuvers make it appear that the restriction of reading materials is about punishment, not 'safety.' [The] Arizona Department of Corrections (ADC) has continually cut programming and opportunities for people inside, meaning sometimes their only option for stimulation or education is a book from the outside (ibid.)

Responses from all the interviewed organizations offered first-hand encounters with both arbitrary and biased censorship. 
Perhaps the most disheartening illustration of bias censorship was uncovered from the interview with Chicago's Liberation Library. The organization, which serves incarcerated youths, is often obstructed by internal challenges within any particular prison. A Liberation Library representative reported that when children were given the opportunity to curate wish lists, the organization received the lists with requested titles already crossed out (Nelson 2019). The crossed-out titles were mainly from the urban fiction genre. For example, a blanket ban was placed on best-selling author, American History and African Studies scholar, and well-known activist, Sista Souljah. For many, Sista Souljah's works speak to their lived experiences of racial oppression, sexism, and urban culture. Her novels are particularly popular in U.S. prisons. In fact, she is credited for popularizing urban literature, a genre originated by incarcerated writers ( $\mathrm{D}^{\prime}$ Addario 2015).

The interviews not only provided evidence of bias book banning practices, but also revealed some of the digital projects already implemented by volunteers and scholars. Luckily, the prototyping process for developing digital tools did not begin with a completely blank slate. Both Inside Books Project and Big House Books shared with me their previous efforts to curate and disseminate data. Aems Emswiler, a volunteer and scholar from Inside Books Project, is already employing digital humanities through a community-based archiving project which digitizes book denial forms from the Texas Department of Criminal Justice (Emswiler 2019). The site is run on Omeka, an open-source content management system. Additionally, Big House Books constructed a password-protected database which keeps inventory of the titles that they send out (Mississippi Big House Books 2019). Receiving access to these projects allowed me to evaluate the ways in which digital tools succeed and where there is opportunity for growth and improvements.

The findings uncovered in the interview process support this study's thesis that publishing book denial data leads to more opportunities to refute bans. For example, Emswiler's Omeka website published a book denial form for Stephen Duncombe's, Cultural Resistance Reader. The reason for the ban, according to the TDCJ, was that the text "contains material that a reasonable person would construe as written solely for the purpose of communicating information to achieve the breakdown of prisons through offender disruption such as strikes, riot, or security threat group activity" (Texas Department of Criminal Justice (2017)). When contacted through email, Duncombe expressed skepticism, as the pages in question did not align with any one essay in the reader. He responds,

Instead, they encompass the last few pages of an essay On "Cultural and Anarchy" by the 19th Century cultural conservative Matthew Arnold, who argues for the importance of Elite culture as a way to stem the tide of what he was as the anarchy of Industrialism and class politics in the UK, and the first few pages of "The Prison Notebooks," by the early 20th Century Italian Marxist Antonio Gramsci writing, from a Fascist prison, about the importance of culture in the challenge and maintenance of hegemonic power. The only thing that makes sense with the page spread censored is that the censor saw the words "Anarchy" and "Prison" in the two titles, put them together, and without ever opening the book decided that this must constitute some sort of threat. I don't know whether to be horrified or relieved that our censors are so inept. (Duncombe 2020)

Emswiler's Omeka website serves as an example for how digital projects can bridge the barrier between prison policies and public awareness. Furthermore, as demonstrated by Duncombe, when authors gain awareness of their banned book, they are offered the chance to retort prison officials' bans. Although this particular website has published a handful of book denial forms, it only scratches the surface of the awareness that data consolidation and digital tools can accomplish.

The inquiry into the efficacy of technology and digital tools for expanding prisoners' access to texts garnered mixed responses. Although Read between the Bars stated that "more transparency and accountability is needed, and this could be possible digitally" (Read between the Bars 2019) other organizations indicated difficulty implementing such tools. Books to Prisoners stated that "we 
don't have a dedicated tech person, [and] digital tools get into disrepair too quickly."7 At this point, mitigating the burden of technology upkeep while engendering advocacy through digital awareness became the primary focus of this project.

\section{Digital Humanities as Possible Intervention}

Digital humanities (DH) refers to an area of scholarship which intersects computational science with traditional humanities research, with the objective of achieving more data-driven analyses and visualizations. One key function of $\mathrm{DH}$ is the transcendence of highly individualized and subject-specific scholarship onto more collaborative and multidisciplinary modes of scholarship production. As a consequence, knowledge is disseminated to a much broader audience of scholars, professionals, activists, and the general public. Therefore, $\mathrm{DH}$ has become an invaluable social justice tool, as it shifts the production of information outside of the confines of the academy and unto a more generalized audience.

Columbia University's Group for Experimental Methods in the Humanities, XPMethod, exemplifies the benefits of collaboration as a DH tool. XPMethod deployed Torn Apart last year, a mapping initiative that aims to track the elusive locations of U.S. federal and private juvenile detention centers, which are currently detaining immigrant children (Torn Apart/Separados 2018). The project's mission is to uncover "a shadowy network of government facilities, subcontractors from the prison-industrial complex, 'non-profit' administrators paid over half a million dollars a year, and religious organizations across the country, that, together, prop up the immigrant detention machine" (When Digital Humanities Meets Activism 2018). Since Torn Apart responds to a timely political debate, it has a shorter production rate than more conventional humanities research. In order to realize its goals, XPMethod employed academics from other institutions, as well as artists and activists who were not affiliated with any institutions of higher education. This is just one example of how individuals outside of the academy are contributing to scholarly conversations about humanistic inquiry and social justice. Moreover, Torn Apart serves as a model for how this study approaches collaborative, data-driven, social justice digital projects.

\section{Prototyping a Potential Solution}

Like Torn Apart, this project invokes collaboration as a means of enriching the data curation process. By collaborating with books-to-prison organizations, the interview and research process allowed me to observe first-hand accounts of the obstacles in the way of providing books to prisoners and work collaboratively toward discovering potential DH solutions for said obstacles. For the project at the focus of this study, the data simply does not exist within the academy, nor does the solution. Currently, data about banned books is unstructured, and primarily comes from three sources-journalism, denial forms, and some state-published lists. Since the data is segregated and unstandardized, anyone attempting to conduct data-driven, evidence-based strategies for analyzing the banned corpus, will ultimately face substantial challenges. Therefore, activists must turn to communities affected by arbitrary book banning practices, and the grassroots organizations who work tirelessly to serve them.

A potential solution is the advent of a collaborative database and community archive. Community-based online archives, as described by Emily Monks-Leeson in American Archivist, are "websites created by individuals, organizations, or institutions who presumably have little or no grounding in archival theory yet desire to make historical material accessible in digital form" (Monks-Leeson 2011). With this in mind, the prototype demonstrates an example of a transparent repository where books-to-prison organizations and individuals could regularly document book challenges and share them with the public. The central feature of the prototype is the consolidation of

7 Books to Prisoners. Interview by Kate Cauley. 13 March 2019. 
structured book denial data, which allows for more simple discovery, visualization, and interpretation of the censorship practices currently plaguing United States' prisons. The advantages of instating a collaborative data repository have been examined by digital humanist and database scholar, Stephen Ramsey:

The successful employment of such systems in humanistic contexts, however, would expand the possibilities of knowledge representation considerably. Since the data would enter into the system from a number of different sources, the logical statements that would flow from that ontology would necessarily exceed the knowledge of any one individual. (Ramsay 2004, p. 195)

Relying on the higher courts, individual states, or prison officials to report on banned materials, particularly bans which present obvious First Amendment violations, will not suffice. Activism, like DH, is a collaborative effort. Therefore, the first step toward achieving accurate data aggregation is the prototyping, and subsequent deployment of a community-powered outlet for reporting banned books.

The ideal vision for this digital project is a consolidated website for banned books data. During this project's preliminary research phase, various media formats were tirelessly shifted through in the search for data. This is a needlessly involved task for any scholar, activist, or citizen looking to obtain censorship data. To resolve this issue, the prototype illustrates a website, which acts as a repository for the books-to-prison community to collect authoritative data. Permissions are granted to organizations and individuals which allow for data contributions. Contributors may include books-to-prison organizations, authors, activists, formerly incarcerated individuals, and the friends and families of incarcerated individuals. Since contributions are permissions-based, records are authoritative. The open-source database offers enriched metadata and simple export functions. The objective of this project is to create a digital repository in which data standardization is both achievable and simple. Therefore, design and usability were both key components towards producing a potential universal tool.

While developing a collaborative database prototype, special attention was paid to issues of feasibility and design. The interviews reiterated the lack of technological support facing books-to-prison organizations, and therefore, examining solutions from a feasibility standpoint became paramount. Various platforms were considered, including Google Sheets or directly hosting a SQL database on the web. After careful deliberation, the cloud collaboration service, Airtable (Figure 1) was deemed to be the most appropriate platform to use. Airtable "works like a spreadsheet but gives you the power of a database to organize anything." ${ }^{8}$ The spreadsheet-database hybrid acts as a user-friendly relational database, with the added benefit of built-in functions which facilitate easy collaboration. For example, Airtable has the ability to connect directly to Slack (Figure 2). This is useful since many volunteers are already communicating through a shared Slack channel. Airtable is a feasible platform, because its versatile and user-oriented design reinforces the ability to gain crowd-sourced participation.

Another consideration for the prototype was the role of data standardization toward achieving transparency. Since the current state of banned books data lacks uniformity, accessing metadata and making connections between different prisons is a great challenge. Therefore, implementing a universalized schema allows for more easily interpretable data across all states, books-to-prison organizations, and prisons. Airtable has uniquely detailed metadata options, which allow the creator to customize data types for each table row. For example, an important aspect of this prototype is quality citation data. Tracking the source of information is essential to maintaining data standards. Thus, the prototype's main spreadsheet is linked to a citation table (Figure 3). In the citation table, fields are customized as URL, image, and text format. URL fields link to digital resources which cite the ban and image fields display scans of handwritten book denial form (Figure 4). This process tracks

8 AirTable, 2020, accessed 29 January 2020, airtable.com. 
the type of data currently available on banned books, and where it comes from, in order to achieve both accuracy and transparency.

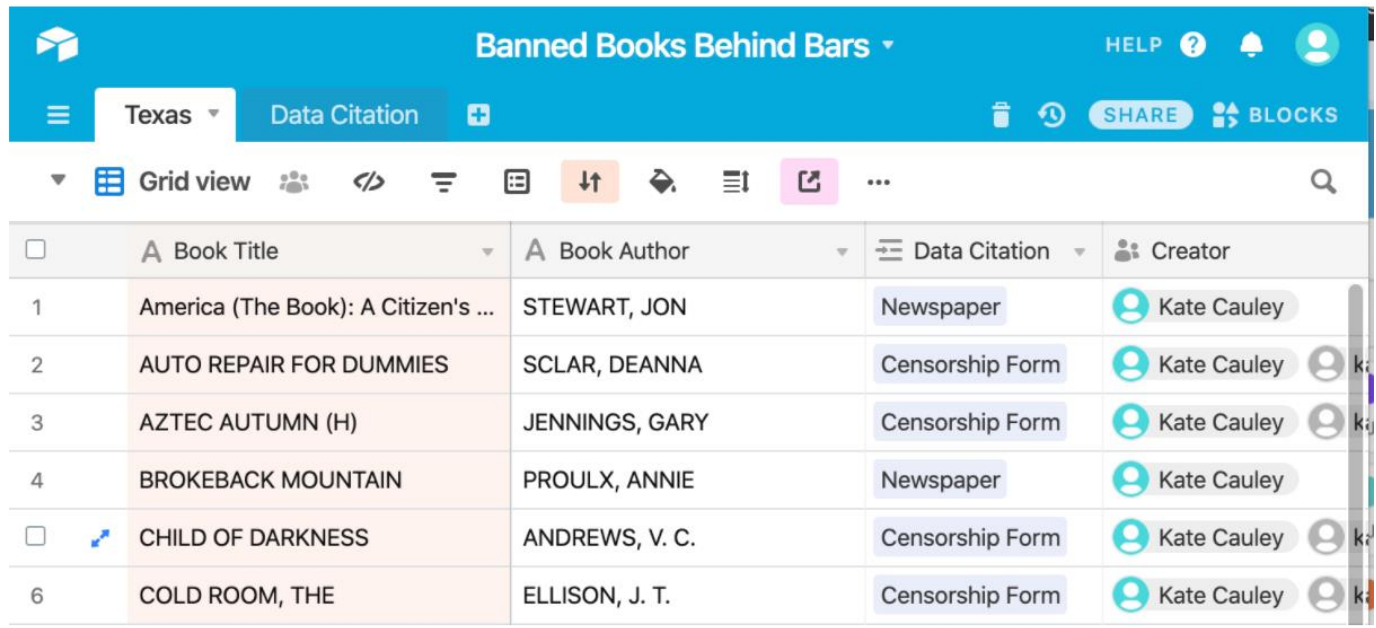

Figure 1. Airtable's graphical user interface is simple to navigate and offers a host of useful functions (Airtable, 2020, accessed 29 January 2020, airtable.com).

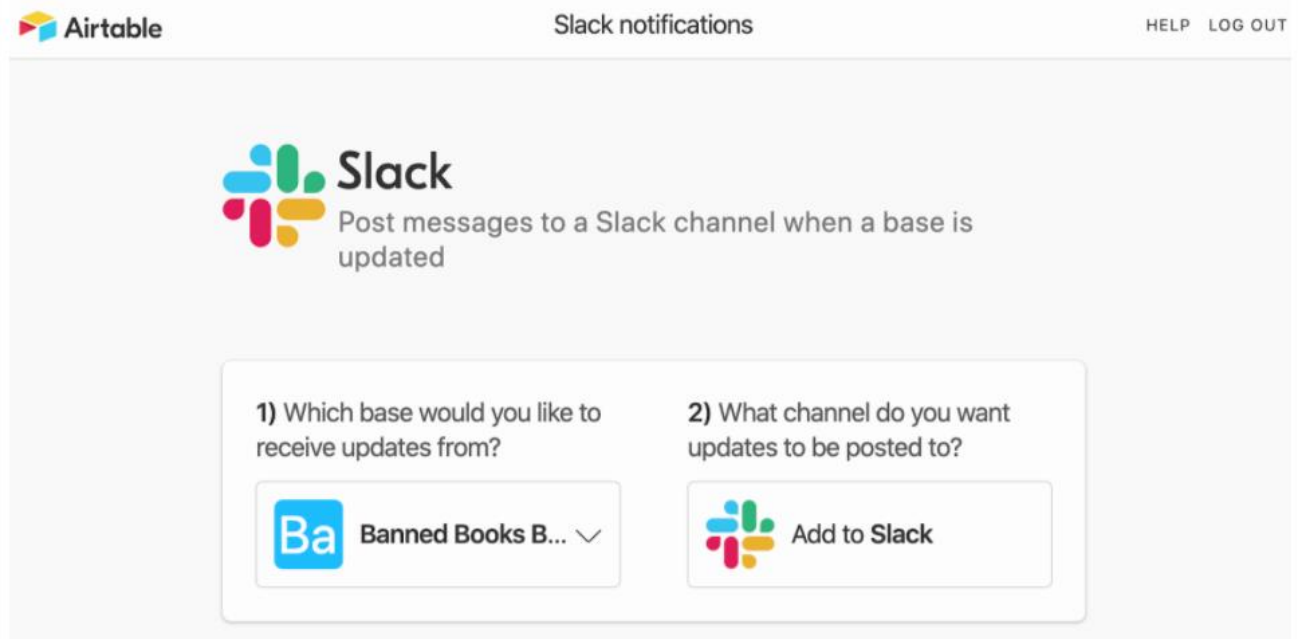

Figure 2. Airtable offers a simple avenue for communication through your organization's shared slack channel (Airtable, 2020, accessed 29 January 2020, airtable.com).

\begin{tabular}{|c|c|c|c|c|}
\hline A Data Type & $\underline{\equiv}$ Book Title & ๘ URL Citation & D I... & $\underline{\underline{A}}=$ Denial Citation \\
\hline Newspaper & COLOR PURPLE (THE) & https://www.texastri... & & None \\
\hline Censorship Form & COMING OF AGE IN MISSISSIPPI & https://insidebooksar... & 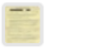 & (d) a specific determinati... \\
\hline Censorship Form & DRAGON SYNDICATES & https://insidebooksar... & - & (c) It contains material th... \\
\hline State Spreadsheet & EIGHT MEN & https://www.blackra... & & (c) It contains material th... \\
\hline Censorship Form & EXCLUSIVE & https://insidebooksar... & 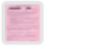 & (d) A specific determinat... \\
\hline State Spreadsheet & GETTING STARTED IN ELECTRONIC & https://www.blackra... & & (e) It contains material o... \\
\hline Censorship Form & LAUNDRYMAN, THE & https://insidebooksar... & $\cdots$ & (e) It contains material o... \\
\hline
\end{tabular}

Figure 3. The citation page of the database provides metadata on each book denial. This may include a URL link to the reported ban, a signed denial form from a prison, or a link to a statewide list of banned books (Airtable, 2020, accessed 29 January 2020, airtable.com). 


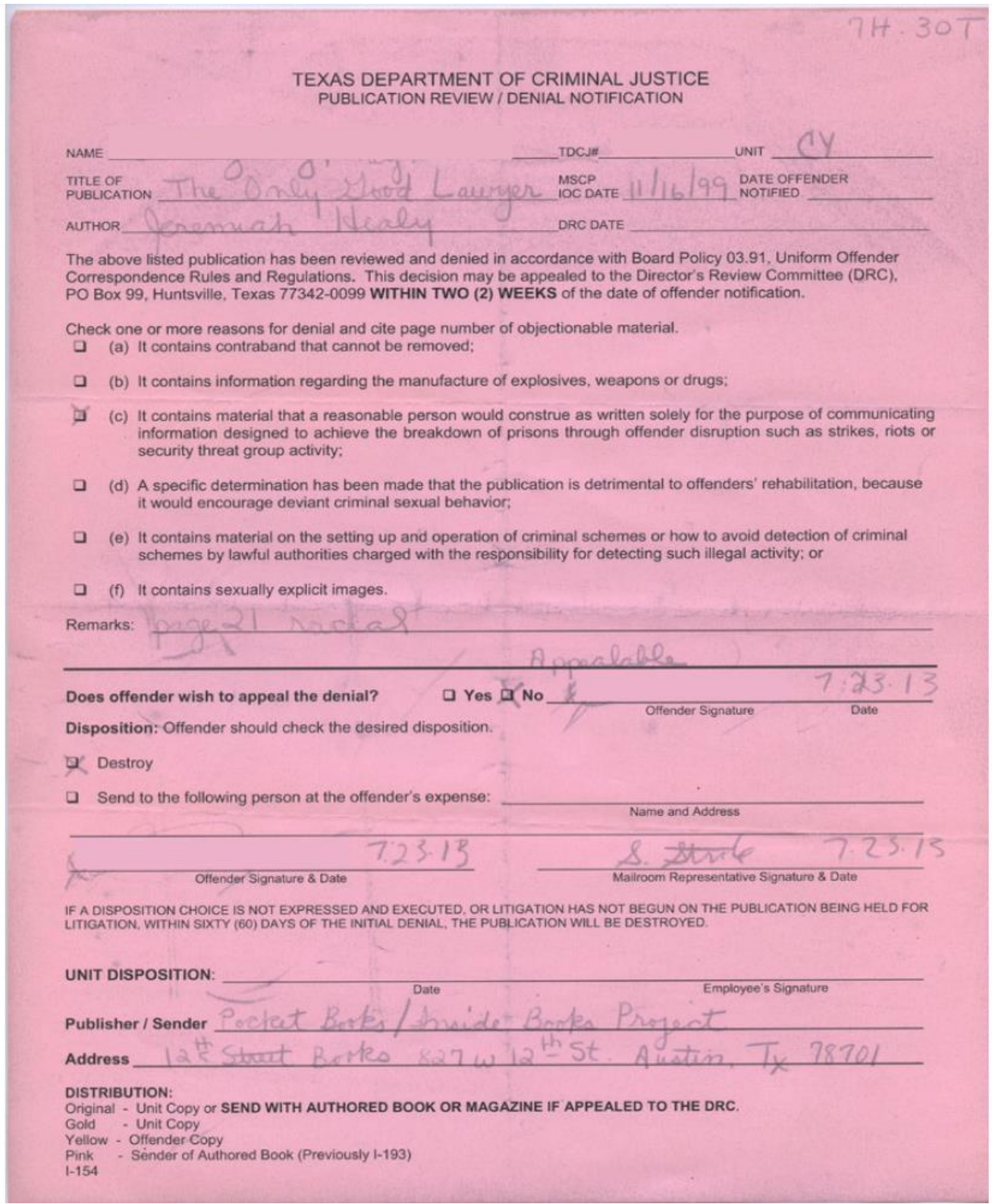

Figure 4. A Texas Department of Criminal Justice denial from for the book The Only Good Lawyer. The "remarks" section simply says "racial" as justification for its denial. This image was shared by a generous volunteer at Inside Books Project, aems Emswiler. All personal identifiable information has been redacted. Texas Department of Crimial Justice (TDCJ) "Denial form for The Only Good Lawyer by Jeremiah Healy" (Inside Books Project Archive, accessed 26 April 2020, https://insidebooksarchive. omeka.net/item/show/149).

The primary objective of this project is to establish a data initiative amongst books-to-prison organizations in order to facilitate activism. Iteration is a key part of the creation process, as the prototype will undergo several revisions before deployment of a live digital project. Therefore, the next step for this project is to share this study's findings, wireframes, and sample Airtable datasets with collaborators. Afterwards, adjustments will be made in order to incorporate feedback from the books-to-prison community.

The utmost goal of this project is to use data as a political argument. This is achievable through data consolidation, matched with scholarly citations about the data's derivation. 
This paper shows how DH presents an opportunity for progressive awareness and transparency on the issues surrounding unjust banning practices in U.S. prisons.

\section{Why Books Matter: The Relationship between Knowledge and Power}

Reading produces knowledge, and knowledge facilitates power. According to Michel Foucault, the relationship between knowledge and power is the primary mechanism for modern prisons. In Foucault's Discipline E Punish, "power" refers to disciplinary control. He defines judicial control and knowledge as being directly associated with one another, a social construct which he coins "epistemologico-juridical formation" (Foucault 1995, p. 23). This "technology of power" (ibid.), to which he refers, shifts the form of punishment from monarchical executions unto more covert methods of controlling the bodies of convicts. Therefore, during modernity, punishment is no longer a gruesome public spectacle meant to shock and deter citizens from committing punishable acts of crime. Instead, new mechanisms of control emerge, making the bodies of the convicted docile. This shift marks the age of contemporary prison, where criminals are no longer controlled by physical punishment to their bodies, but rather by redefining knowledge production to benefit those in power. If Foucault is correct about the symbiosis between knowledge and power, then banning books is, therefore, an apparatus of disciplinary control.

One of the main goals of the prison system is to reduce recidivism, so that formerly incarcerated individuals can enter back into their communities as reformed, contributing, citizens. One effective way to accomplish this goal is through prison education (Davis et al. 2013). This information is not new, and yet prison administrators continue to ban books at alarming rates. In fact, studies have linked a substantial correlation between education and recidivism rates for decades (Hall 2015). The Rand Corporation reports that "inmates who participate in correctional education programs had 43 percent lower odds of recidivating than those who did not" (Davis et al. 2013, p. xvi).

Limiting access to knowledge not only affects the lives of individuals behind prison walls, but also impacts the greater society. Investing in prison education programs, as well as allowing prisoners' access to books and informational materials which aid in their educational pursuits, will ultimately lead to a lower prison population. This is important because it is estimated that every dollar spent on prison education yields a return of four-five dollars in taxpayer savings on incarceration costs (Expanding Access to Postsecondary Education in Prison 2017) Therefore, making efforts to reduce recidivism rates will not only benefit individuals and communities directly suffering from the impacts of the prison-industrial complex, but also allow for taxpayer dollars to be allocated elsewhere.

Correctional education may result in reduced recidivism rates and reallocated tax dollars, but it is also a fundamental human right. Article 26 of the United Nations' "Universal Declaration of Human Rights" states that all people have a right to education. In case there is any question on whether this right is extended to incarcerated individuals, David Atchoarena, Director of the UNESCO Institute for Lifelong Learning, clarifies "the time spent in prison should ideally help them to continue or return to learning, and give them the chance to experience the joy of having access to reading materials for education, self-reflection or simply recreation" (Krolak 2019).

\section{Conclusions}

The United States' problem with mass incarceration is so formidable that a reported $91 \%$ of Americans support criminal justice reform (American Civil Liberties Union n.d.). However, other nations have surpassed the United States' efforts to lower recidivism through education. In Brazil, where prisons were reported at 167\% occupancy in 2011 (Castillo 2012), a "Reading through Redemption" program was established to shorten sentences and facilitate learning. Brazilian prisoners are encouraged to read up to twelve books a year; in exchange, they could shave four days per book report off of their sentences. Although this does not single-handedly reform a troubled prison system, it offers prisoners a chance at redemption, a deeper understanding of social and cultural concepts, and for those who lack formal education, an opportunity to develop basic literacy. Brazil's ideologies 
toward redemption and prioritization of correctional education serve as a prime example for how the United States can achieve similar reform.

$\mathrm{DH}$ is a powerful instrument for social good, as modern society relies on digital technologies for the dissemination of knowledge. Widening the audience of knowledge consumption, through the use of digital tools, is a pathway toward achieving a more just and equal power relationship within the criminal justice system. The project proposed in this paper aims to achieve this by consolidating influential data on banned books, which can be used as a resource to return First Amendment rights back to the incarcerated. Through consulting books-to-prison organizations, input was received on feasibility which will lead into the next iteration of this data initiative. A database for banned books, such as the one proposed in this paper, will play a part in holding this system of oppression accountable by promoting transparency within censorship practices, making an important contribution to the protection of First Amendment rights to people in prison.

Funding: This research received no external funding.

Conflicts of Interest: The author declares no conflict of interest.

\section{References and Notes}

American Civil Liberties Union. n.d. 91 Percent of Americans Support Criminal Justice Reform, ACLU Polling Finds. Available online: https://www.aclu.org/press-releases/91-percent-americans-support-criminal-justicereform-aclu-polling-finds (accessed on 16 October 2020).

Bromwich, Jonah Engel. 2018. Why Are American Prisons So Afraid of This Book? The New York Times, January 18. Available online: https:/www.nytimes.com/2018/01/18/us/new-jim-crow-book-ban-prison.html (accessed on 18 January 2018).

Bianco, Alicia. 2016. Prisoners' Fundamental Right to Read: Courts Should Ensure That Rational Basis Is Truly Rational. Roger Williams University Law Review 21: 1.

Blichfeldt, Bodil, and Jesper Andersen. 2006. Creating a Wider Audience for Action Research: Learning from Case-Study Research. Journal of Research Practice 2: D2.

Burns, Anna C. 2007. Beard V. Banks: Restricted Reading, Rehabilitation, and Prisoners' First Amendment Rights. Journal of Law and Policy 15: 1225-70.

Castillo, Mariano. 2012. Brazilian Inmates Reduce Sentences by Hitting the Bike, Books. CNN, July 15. Available online: https:/www.cnn.com/2012/07/14/world/americas/brazil-alternative-sentence-reduction/ index.html (accessed on 15 July 2012).

D'Addario, Daniel. 2015. Sister Souljah's New Moment. TIME Magazine 186: 44-45.

Davis, Angela Y. 2003. Are Prisons Obsolete? New York: Seven Stories Press.

Davis, Lois M., Robert Bozick, Jennifer L. Steele, Jessica Saunders, and Jeremy N. V. Miles. 2013. Evaluating the Effectiveness of Correctional Education: A Meta-Analysis of Programs That Provide Education to Incarcerated Adults. Santa Monica: RAND Corporation.

Dean, Al M. 2016. Turner, Thornburgh, and an Inmate's Right to Read: The Chelsea Manning Case and Possible Solutions to Bop and Usdb Regulation Language. Vermont Law Review 41: 635. [CrossRef]

Duncombe, Stephen. 2020. Interview by Kate Cauley. Email Interview.

Emswiler, aems. 2019. Interview by Kate Cauley. Austin: Inside Books Project, June 21.

Expanding Access to Postsecondary Education in Prison. 2017. Available online: https://www.vera.org/ publications/postsecondary-education-in-prison-fact-sheet-for-correction-leaders (accessed on 1 May 2019).

Foucault, Michel. 1995. Discipline and Punish: The Birth of the Prison, 2nd ed. New York: Vintage Books.

Haag, Matthew. 2017. Texas Prisons Ban 10,000 Books. No ‘Charlie Brown Christmas' for Inmates. The New York Times, Gale. December 7. Available online: https://link.gale.com/apps/doc/A517848280/AONE?u=nysl_me_ newyorku\&sid=AONE\&xid=b623f417 (accessed on 1 May 2019).

Hall, Lori L. 2015. Correctional Education and Recidivism: Toward a Tool for Reduction. Journal of Correctional Education 66: 4-29.

James, Cullen. 2018. The History of Mass Incarceration. New York: Brennan Center for Justice, Updated 20 July 2018. Available online: https://www.brennancenter.org/our-work/analysis-opinion/history-mass-incarceration (accessed on 15 April 2020). 
Jones, Derek. 2001. Censorship: A World Encyclopedia. London and Chicago: Fitzroy Dearborn.

Krolak, Lisa. 2019. Books beyond Bars: The Transformative Potential of Prison Libraries. Hamburg: UNESCO Institute for Lifelong Learning, Available online: https://uil.unesco.org/adult-education/books-beyond-barstransformative-potential-prison-libraries (accessed on 1 May 2020).

Leins, Casey. 2019. 10 States with the Highest Incarceration Rates. Available online: https://www.usnews. $\mathrm{com} /$ news/best-states/slideshows/10-states-with-the-highest-incarceration-rates?slide=8 (accessed on 28 May 2019).

Louisiana Department of Corrections List of Banned Books and Publications. 2018. Updated 12 July 2018. Available online: https://www.scribdc.com/document/394398095/Louisiana-Department-of-Corrections-listof-banned-books-and-publications (accessed on 12 December 2019).

Mississippi Big House Books. 2019. Interview by Kate Cauley. E-mail. April 26.

Monks-Leeson, Emily. 2011. Archives on the Internet: Representing Contexts and Provenance from Repository to Website. American Archivist 74: 38-57.

Nelson, Jocelyn. 2019. Interview by Kate Cauley. Chicago: Liberation Library, April 29.

O'Sullivan, Joseph. 2019. Washington Corrections Officials Reverse Ban, Will Allow Prisoners to Get Used Books in the Mail. Seattle Times, April 10. Available online: https://www.seattletimes.com/seattle-news/politics/ washington-corrections-officials-reverse-ban-will-allow-prisoners-to-get-used-books-in-the-mail/ (accessed on 10 April 2019).

PEN America. 2019. Literature Locked Up: How Prison Book Restriction Policies Constitute the Nation's Largest Book Ban. PEN America, September 24. Available online: https://pen.org/wp-content/uploads/2019/09/ literature-locked-up-report-9.24.19.pdf (accessed on 1 May 2020).

Ramsay, Stephen. 2004. A Companion to Digital Humanities. In Blackwell Companions to Literature and Culture. Edited by Susan Schreibman, Ray Siemens, John Unsworth and Roberto A. Busa. Malden: Blackwell, vol. 26, pp. 177-97.

Read between the Bars. 2019. Interview by Kate Cauley. March 21.

Reason, Peter, and Hilary Bradbury. 2008. The Sage Handbook of Action Research. Thousand Oaks: SAGE Publications Ltd., Available online: https://methods.sagepub.com/book/the-sage-handbook-of-actionresearch (accessed on 1 May 2019).

Sullivan, Larry E. 1990. The Prison Reform Movement: Forlorn Hope. Boston: Twayne Publishers.

Texas Civil Rights Project. 2011. Banned Books in the Texas Prison System: How the Texas Department of Criminal Justice Censors Books Sent to Prisoners. Available online: https:/www.prisonlegalnews.org/media/publications/texas_ civil_rights_project_prison_book_censorship_report_2011.pdf (accessed on 1 May 2019).

Texas Department of Criminal Justice (TDCJ). 2017. Denial Form for 'Cultural Resistance Reader' by Stephen Duncomb.Inside Books Project Archive. Available online: https://insidebooksarchive.omeka.net/items/show/ 166 (accessed on 16 October 2020).

Texas Department of Criminal Justice (TDCJ). 2020. Denial form for "The Only Good Lawyer" by Jeremiah Healy. Inside Books Project Archive. Available online: https://insidebooksarchive.omeka.net/items/show/149 (accessed on 22 April 2020).

Torn Apart/Separados. 2018. Available online: http://xpmethod.plaintext.in/torn-apart/volume/2/index (accessed on 22 April 2020).

When Digital Humanities Meets Activism. 2018. Inside Higher Ed. Updated 9 July 2018. Available online: www. insidehighered.com/news/2018/07/09/when-digital-humanities-meets-activism (accessed on 1 May 2019).

Yee, Min S. 1973. The Melancholy History of Soledad Prison; in Which a Utopian Scheme Turns Bedlam, 1st ed. New York: Harper's Magazine Press.

Publisher's Note: MDPI stays neutral with regard to jurisdictional claims in published maps and institutional affiliations.

(C) 2020 by the author. Licensee MDPI, Basel, Switzerland. This article is an open access article distributed under the terms and conditions of the Creative Commons Attribution (CC BY) license (http://creativecommons.org/licenses/by/4.0/). 